\title{
Developing Gender-Based Justice Relationships in Indonesian Families During the COVID-19 Pandemic
}

\author{
Yeni Huriani ${ }^{*}$ \\ (UIN Sunan Gunung Djati Bandung) \\ Mohammad Taufiq Rahman ${ }^{2}$ \\ (UIN Sunan Gunung Djati Bandung) \\ Mochamad Ziaul Haq 3 \\ (Open Integrity Program of Indonesia's RSCJ)
}

fikrakoe@uinsgd.ac.id

em zya@yahoo.com

yenihuriani@uinsgd.ac.id

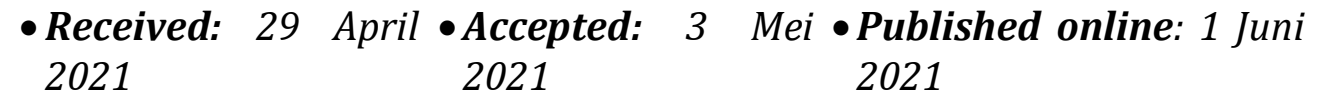

\begin{abstract}
:
Dengan situasi Bekerja dari Rumah (WFH) dan Belajar dari Rumah (SFH) selama Pandemi COVID-19, tanggung jawab keluarga perempuan telah meningkat. Hal tersebut menyebabkan terjadinya kekerasan dalam rumah tangga, kekerasan pasangan intim (IPV), kesehatan mental, dan tingginya resiko kekerasan terhadap anak, terutama anak perempuan. Studi ini menggunakan perspektif studi perempuan dengan pendekatan kualitatif dalam mengamati dan menganalisis secara kritis perkembangan pandemi COVID-19 yang menimpa perempuan selama tahun 2020, baik berdasarkan observasi langsung, studi literatur hasil penelitian dampak pandemi, serta berbagai laporan yang dipublikasikan oleh Pemerintah dan media swasta terpercaya. Studi ini menemukan bahwa pandemi dapat menciptakan realitas baru dalam relasi berbasis gender dalam rumah tangga, yaitu: membangun konstruksi baru relasi gender; dari kesetaraan gender hingga keadilan relasi kuasa berbasis gender; mengubah tanggung jawab pengasuhan dari mengandalkan ibu menjadi tanggung jawab orang tua secara kolektif; kebutuhan untuk meningkatkan pengaturan untuk pembagian kerja yang adil dalam pekerjaan dan perawatan di rumah. Artikel ini menggunakan kajian perempuan dalam menganalisis dan mengembangkan wacana kritis tentang keadilan relasi kekuasaan gender dalam keluarga di tengah pandemi yang memberi tekanan pada perempuan di Indonesia, terutama karena tuntutan WFH dan SFH.
\end{abstract}

Kata kunci: kesehatan mental; kesetaraan gender; kekerasan dalam rumah tangga; mengasuh anak; studi wanita.

\footnotetext{
Abstract

*Yeni Huriani, yenihuriani@uinsgd.ac.id

Copyright@ 2021 Yeni Huriani, Mohammad Taufiq Rahman, Mochamad Ziaul Haq. Equalita: Jurnal Studi Gender dan Anak
} 
With the Work from Home (WFH) and Study from Home (SFH) situations during COVID-19 Pandemic, women's family responsibilities have increased. It has led to domestic violence, intimate partner violence (IPV), mental health, and a high risk of violence against children, especially girls. This study uses the perspective of women's studies. It is qualitative in observing and critically analyzing the development of the COVID-19 Pandemic that befell women during 2020, both based on direct observation, literature studies on pandemic impact research results, and various reports published by the Government and reliable private media. This study finds that a pandemic can create new realities in gender-based relations in households, namely: building new constructions of gender relations; from gender equality to gender-based power relations justice; change the responsibility of care from being relying on the mother to being the responsibility of the parents collectively; the need to improve arrangements and arrangements for the equitable division of labor in work and home care. This article uses women's studies in analyzing and developing critical discourse on the justice of gender power relations in the family amid a pandemic that puts pressure on women in Indonesia, primarily due to the demands of WFH and SFH.

Keywords: mental health; gender equality; domestic violence; child-rearing; women studies.

\section{A. INTRODUCTION}

At the end of 2019, humans faced a systemic humanitarian crisis (Organization, 2020b). The COVID-19 virus has been genetically identified and sequenced related to other coronaviruses circulating in bats (including the SARS coronavirus). It led to the belief that these flying mammals may be natural carriers. The point of contact with humans could have come from a live animal market in Wuhan, and the virus went undetected for several weeks in the city of 11 million people. The leap of viruses from animals to humans (spillovers) is common among coronaviruses. It happened with SARS (2002-2003) and MERS (2012). It has been proven that the 2019-nCoV virus is easily transmitted from person to person because the group of intra-family cases and transmission to health personnel has been identified and continues to increase sharply at the start of the Pandemic (Trilla, 2020).

In February 2020, the World Health Organization (WHO) identified COVID-19 as the virus that causes "severe acute respiratory syndrome" and declared it a pandemic. On February 18, 2020, WHO reported 804 confirmed cases and three deaths in 25 countries outside China. In addition to confirmed cases from travelers to Wuhan and on cruise ships, countries including Singapore, Japan, Thailand, and South Korea have identified clusters of locally transmitted cases. The numbers are small, but the transmission rate is alarmingly increasing, accompanied by misinformation that causes widespread fear (The Lancet, 2020). 
Furthermore, this Pandemic affected 223 countries with a positive confirmed number of 109,594,835 people and caused 2,424,060 deaths (WHO, 20/02/2021). The first Covid-19 case in Indonesia was confirmed on March 2, 2020. The victims were two women of 31 and 64 years. It was announced by President Joko Widodo (Jokowi). As of May 8, 2020, there were 12,776 cases and 930 deaths reported in 34 provinces. Furthermore, there are 1,263,299 Covid-19 positive people in Indonesia, a total of 1,069,005 people have recovered, and 34,152 died (Covid19.go.id, 08/05/2021).

Two women were confirmed positive for COVID-19 opened broader horizons about women's vulnerability in Indonesia. Based on the Central Statistics Agency (BPS), the Indonesian population census has increased male residents number. The 2020 population census suggests an increase in the sex ratio of Indonesia's population; there are 102 men for every 100 women (Badan Pusat Statistik, 2020). With a patriarchal culture in Indonesia, the data shows that for every 100 household heads, 85 people are men and 15 are women (B P Statistik, 2018). In an emergency, women suddenly return to their traditional roles. The policy of physical distancing and large-scale social restrictions (PSBB) causes the activities of working at home or Work from Home (WFH) and School from Home (SFH) to increase the dual role of women (Power, 2020).

This research examines the development of the Pandemic's impact in Indonesia and various research results during 2020, which discuss women's vulnerability in this crisis. The Policy Brief on The Impact of Covid-19 on Women (Organization, 2020a) stated that the Covid-19 Pandemic deepened economic and social pressures coupled with restrictions on movement and social isolation. Gender-based violence increased exponentially. This Pandemic has an impact on all sectors of human life, including a significant effect on women. Research from UNDP states that the COVID-19 crisis has greatly affected women and girls in facing specific and disproportionate economic, health, and social risks due to inequality in gender power relations rooted in society and even become a social norm. Understanding the impact of a pandemic in gender relations opens findings and policy responses to strengthen gender equality for women amid a pandemic (Power, 2020). This crisis deepens pre-existing inequalities even further, exposing the vulnerability of the social, political, and economic systems, which exacerbates the Pandemic's impact (Guterres, 2020). 
The problems of equality in gender power relations have been going on for a long time. Still, the Pandemic has provided a different space in building gender equality that is more just and established, both at the national and global levels. The phenomena and data above will be studied critically to reveal the urgency of justice in gender power relations in families amid a pandemic, especially from the demands of Work from Home (WFH) and Studying from Home (SFH) that cannot be avoided anymore.

Based on the UNICEF report (UNICEF, 2020), regional quarantine has worsened the risk factors for child violence, abuse, and neglect. Before the Pandemic, the level of child abuse in Indonesia was high: 60 percent of children between the ages of 13 and 17 stated that they had experienced some form of violence (physical, psychological/emotional, or sexual) during their lifetime. The risk factor is quite worrying for the younger generation, especially coupled with the high tolerance for domestic violence in Indonesia. Also, one in nine women married before turning 18 years of age. In marriage, these women tend to be more prone to domestic violence due to the family's inequality of husband-wife roles.

Many reports from other countries show an increase in domestic violence against children due to regional quarantine implementation. These concerns are related to family income and increasing pressure on parents and caregivers to look after them and help them study. The closure of daycares and schools places more burdens on families and institutions to ensure children's growth and development. Children cannot have social interactions at school and play outside. Two things are essential to support their learning and development. Besides, most households in Indonesia live in tight spaces. One-third of them live in an area of less than 50 square meters. This situation will create an extraordinary stress level that can lead to violence (UNICEF, 2020).

\section{B. RESEARCH METHOD}

Critical analysis of this research uses qualitative studies of various phenomena and data, both based on direct observation, literature studies on pandemic impact research results, and multiple reports published by reliable Government and private media. This research will analyze various gender relations injustice and the 
vulnerability of women with numerous roles amid the Pandemic, especially in the demands of policies Work from Home (WFH) and School from Home (SFH) in Indonesia. Based on a study of women studies, this research identifies the phenomena of women's emergencies during a pandemic to develop various factors that strengthen gender power relations that are more critically equitable in the family. Academically, this research will build the awareness of researchers with a background in the scientific discipline of women studies in Indonesia to make a critical discourse so that gender equality and gender power relations justice in the family can be scientifically advanced.

Many reports from other countries show an increase in domestic violence against children due to regional quarantine implementation. These concerns are related to family income and increasing pressure on parents and caregivers to look after them and help them study. The closure of daycares and schools places more burdens on families and institutions to ensure children's growth and development. Children cannot have social interactions at school and play outside. Two things are essential to support their learning and development. Besides, most households in Indonesia live in tight spaces. One-third of them live in an area of less than 50 square meters. This situation will create an extraordinary stress level that can lead to violence (UNICEF, 2020).

Practically, this research encourages every woman to fight for themselves and their family fairly without gender-based violence and women's psychological pressure. Awareness of the impact of a pandemic among women will increase their resilience. This Pandemic affects every woman in this world, and every individual must survive consciously and be physically and psychologically healthy. For the male group, this research is expected to open men's awareness to respect women and build fair power relations amidst the various pressures of the pandemic impact that befalls every family in the world.

\section{RESULTS AND DISCUSSION}

The Covid-19 Pandemic is not only a health problem. It is also a big shock for the world community, which exposes the shortcomings of women's public and private regulation on the one hand. On the other hand, various social observations of the 
Yeni Huriani, Mohammad Taufiq Rahman, Mochamad Ziaul Haq

Pandemic confirm that women play multiple roles and are not appreciated enough. On the positive side of this reality, this is the moment for every party, whether male and female, Government and private, academics, and the general public, to acknowledge the sizeable strategic contribution made by women in various life sectors.

In the case of COVID-19, there is a worrying dilemma in handling issues of gender-based violence. Victims must still receive assistance, and officers must consider careful anticipation to avoid spreading the virus. To this end, the Government and various parties in society have issued some statements and guidance documents to help reduce the impact of COVID-19 on women who are at risk of experiencing gender-based violence. While these measures acknowledge the additional burdens that women bear during the Pandemic, they are not sufficient to correct the problem of gender disparities entrenched in our society, affecting both women and children.

From the data above, this research can find factors of unfair gender power relations in the family during the Pandemic, namely: (a) The transfer of children's care and education to other parties; (b) The occurrence of barriers to interaction and communication; (3) There is a failure to fulfill the fundamental rights of the child.

In dealing with these factors, this study proposes elements that can build genderbased power relations justice face new realities during the Pandemic, especially in the WFH and SFH systems' demands. This study found that a pandemic can create new realities in gender-based relations in households, namely: (a) Building new constructions of gender relations; from gender equality to gender-based power relations justice; (b) Changing the responsibility for care from the mother to the responsibility of the parents simultaneously; (c) The need to improve arrangements and agreements for the equitable distribution of responsibilities in work and care at home.

The Covid-19 Pandemic is the worst pandemic since the H1N1 (Spanish flu) pandemic, which occurred in 1918 (Thibaut \& Wijngaarden-Cremers, 2020). The COVID-19 Pandemic has become an unprecedented global crisis. This Pandemic has an impact on all sectors of human life, including a significant effect on women. This crisis deepens pre-existing inequalities, exposing the vulnerabilities of the social, 
political, and economic systems, which exacerbate the Pandemic's impact (Guterres, 2020).

Until now, the Pandemic still has a high mortality rate plus the availability of vaccines that require acceleration accompanied by public anxiety about the vaccine's success. The application of physical distancing has become a primary preventive measure, as have government policies imposed social restrictions. Still, there may be unintended negative consequences of various social conditions, such as decreased economic activity and increased pressure on families resulting from work from home (WFH) and study from home policies. (SFH).

This study observes complex problems between formal and informal work related to various aspects of work and family balance. Before the emergence of the term WFH, there has been much discussion about work done at home or telework. However, both WFH and telework tend to increasingly blur the boundaries between work and family domains, and the division of responsibilities for the roles and status of husband-wife and mother-father in each context of care in the family (Erdirençelebi, 2020; Troup \& Rose, 2012).

Research conducted by Troup \& Rose in 2012, 8 years before the Pandemic, shows telework problems. This research states the importance of family balance through a more equitable distribution of parenting roles as a significant indicator of success in conducting telework, including WFH or SFH. In other words, employees who can share childcare responsibilities tend to be more successful in the curve of some forms of remote work (Troup \& Rose, 2012). These findings point to promising benefits for parents and their children regarding more equitable distribution of care under pressure from social distancing and quarantine due to the Pandemic. All work and education of children are done from home.

The formal arrangements in distance work are also more conducive and satisfying for women than for men. Job satisfaction for women may be related to jobs that enable them to respond to family needs and responsibilities. Also, suppose the division of roles is carried out formally and agreed upon by each family member. In that case, it will create greater control for women over the management of work and family responsibilities to prevent stress and maintain the quality of their work. However, this arrangement will still place more significant pressure on women to 
preserve their family care responsibilities according to their expectations (Altena et al., 2020; Troup \& Rose, 2012).

Another finding, there are broad implications to consider in their work (career development and training) and family (responsibilities and time demands) arrangements when negotiating remote work or WFH arrangements with companies and families. Therefore, each party needs to increase their telework arrangements and flexibility. The reason is that fair and flexible arrangements significantly affect the effectiveness of remote work and each work result's achievement (Wong et al., 2020).

However, WFH or telework systems require extreme caution. Managers need to consider the impact of working from home carefully, not only for WFH actors but also for employees who work from the office (Work from Office). The different types of implementation of this work can create jealousy from staff working at home, thus creating a series of new problems in the office (Koren \& Ayalon, 2020). Another challenge is that there is a trend of success in the WFH curve, but it cannot be denied that there is a harmful opacity due to simultaneously unionizing two domains (Chung et al., 2020).

Therefore, the company must pay attention and discuss policies that regulate the WFH and WFO initiatives' psychological impact to create a new system with effective and satisfying results for all parties in the future. A sound system in regulating WFH and WFO, including SFH, will increase work quality resilience during pandemic stress.

On the other hand, WFH provides women opportunities to place their jobs following their initiatives and responsibilities. Although it is possible that WFH and $\mathrm{SFH}$, which are imposed on the household, become a disturbance in their family life, the combination of work and household care allows for more equitable and mutual respect and control so that it has a better impact. The closeness of these two domains will help to make a more conducive work-life balance that is sustainable. Although undoubtedly, working from home has enabled women to withdraw from office work both physically and emotionally, thus creating a more efficient and satisfying work increase for women (Trougakos et al., 2020).

\section{Increasing the Burden of Women's Roles in the Family}


Globally, many countries are reporting an increase in domestic violence cases following the Pandemic. The activity pressure from the home, both WFH and SFH, burdens the women more in the household. Increasing the household's domestic functions and burdens, plus the social structure of society that is still patriarchal, makes domestic obligations for women multiply, from taking care of the house to ensuring children access education from home, even ensuring family health.

Meanwhile, in Indonesia, as stipulated in the Protocol for Handling Cases of Violence against Women in the Pandemic Period issued by the Deputy for Protection of Women's Rights, the Ministry of Women's Empowerment and Child Protection of the Republic of Indonesia, that with the increase in COVID-19 cases, the Government issued instructions for restricting going out of the house. Even since March 16, 2020, Civil Servants are instructed to work from home. Some private companies impose the exact instructions. The Ministry of Manpower and Institution of Social Security for the employment recorded 2.8 million workers had been laid off during the COVID-19 Pandemic because the companies they worked for were not operating. The high wave of layoffs, loss of community livelihoods, followed by other impacts such as the emergence of the potential for gender-based violence (for example, sexual violence, domestic violence, online gender-based violence, and other forms of violence) experienced by women after the issuance of the determination of COVID-19 as National disaster in Presidential Decree (Keppres) No. 12 of 2020 concerning the Determination of Non-Natural Disaster for the Spread of Corona Virus Disease 2019 (COVID-19) as a National Disaster.

This study examines the occurrence of things that increase the burden on women during a pandemic, including: (a) domestic work remains the primary responsibility of women; (b) WFH and SFH demands continue to be widespread and ongoing, which often under-consider the division of household responsibilities; (c) child care and online learning monitoring ( $\mathrm{SFH}$ ) has always been the task of women, as is the health care of family members, especially the older and those who are sick; (d) When the number of tools available for work (WFH) and online learning (SFH) is limited, this will only become a men's priority task.

Therefore, the Covid-19 Pandemic affects women more than men, both at work (especially in the health and social fields), and at home with increased workloads due 
Yeni Huriani, Mohammad Taufiq Rahman, Mochamad Ziaul Haq

to social restriction and quarantine measures. Worldwide, 70 percent of the health workforce consists of women on the frontline health workers (nurses, midwives, and community health workers). Most of the health facility staff (cleaning, laundry, catering) are women. Finally, reports of physical and verbal attacks on health workers have increased in China, Italy, France, and Singapore (Thibaut \& WijngaardenCremers, 2020).

Besides, it turns out that particular services are for women; The integrated service unit for women's and children's empowerment (UPT P2TP2A), elderly homes, safe houses, and even some unique service rooms (RPK) for women and children experience service limitations due to WFH. With schools and child care centers closed, the limited availability of child care options may be another barrier for women to attend health care visits, as distance limitation measures often prevent women from bringing children to meeting places. Increased social isolation and decreased household mobility and privacy due to the demands of living at home on a large scale impact women's autonomy decision-making on their own choice may be increasingly disrupted (Chen \& Bougie, 2020). Also, because women are more economically affected by the Pandemic, they may be reluctant to seek medical care because of financial incapacities, such as transportation costs, online fees, or medical or other care costs.

On the other hand, women play an essential role in stopping the pandemic infection with the coronavirus or Covid-19, starting from guiding families while at home to being at the forefront of healing Covid-19 as doctors and nurses. Therefore, women are at risk for infection both in health facilities and at home. When working from home, women do more work without pay. Apart from professional work, they are involved in childcare, work, and housekeeping. Women who work in less organized economic sectors are more likely to lose their jobs and get into financial crises (Yap, 2020).

In this situation, of course, women are the vulnerable group of contracting the new coronavirus because they leave the house more often than other family members, either work or meet their food needs. Given the higher vulnerability of women frontline workers and the increased risk of violence against them, special measures must be taken to protect them. Social support is recognized as having a buffering role 
Yeni Huriani, Mohammad Taufiq Rahman, Mochamad Ziaul Haq

in protecting women from stress during a pandemic. Social restrictions can make it more difficult for women to cope with this crisis (Thibaut \& Wijngaarden-Cremers, 2020).

The various economic, social, and physical pressures women face during the Pandemic have undoubtedly negatively impacted mental health. Based on the research results on women's mental health during the Pandemic in Japan, it was found that fear of COVID-19 infection, the negative consequences of social restrictions, including travel restrictions and economic downturns, were found to have a significant relationship with depression symptoms experienced by women. For example, perceptions of risk for COVID-19 infection increase the anxiety score, while perceptions of risk of economic hardship and not receiving informal childcare support influence all factors, including increasing the likelihood of depression.

Depressive symptoms can persist even though there is less fear of contracting COVID-19. This symptom is caused by economic instability and inadequate childcare. Besides, the residence location does not show any statistical association, which suggests that the influence of COVID-19 is not limited to areas with higher reported positive cases. Furthermore, the adverse effects of the unwanted social restriction results that cause economic uncertainty and inadequate childcare substantially impact women's mental well-being (Kabeer et al., 2021).

The double burden that women must bear increases and is able to be vulnerable to domestic violence. The Policy Brief on The Impact of Covid-19 on Women (Organization, 2020a) stated that the Covid-19 Pandemic deepens economic and social pressures coupled with restrictions on movement and social isolation; gender-based violence increases exponentially. The UNICEF Indonesia report states that women can carry more of the burden due to the impact of COVID-19 on child care at home. As in many other countries globally, women in Indonesia perform most of the care duties and spend twice as much time accompanying children than boys. Children who live in poor households and households headed by children, women, or elderly caregivers need support and protection. Children in these households experience a more severe poverty level than those who live in households headed by men. In Indonesia, around 8.2 million children are cared for by elderly caregivers, so there is a higher risk of losing caregivers due to COVID-19. Thus, these children are more prone to experience 
violence, abuse, and poverty. These households have a higher likelihood of falling into poverty, and their caregivers will experience heavier social and economic burdens in situations of pandemics and social restrictions (UNICEF, 2020).

The various situations above can strengthen the conclusion that the burden on women is increasing and having to take care of the household, assisting children's schoolwork, even looking for other family economies. This double burden triggers household conflicts to get stronger, which leads to potential violence. Therefore, women with tenderness are more prone to the risk of violence, anxiety, depression, and post-pandemic stress disorder.

\section{Increased Risk of Domestic Violence}

In a world shaped by the Pandemic and post-pandemic crisis, both men and women have been affected by several economic factors, such as cutting or losing wages, losing jobs, increasing prices of necessities. However, because of how our world and our society are patriarchically structured, women's impact is more pronounced. Based on observations from various family-based violence cases during the Pandemic, this study found several supporting factors for the injustice of gender power relations during the Pandemic.

We can observe that the narrow and confined spaces have resulted in increased levels of stress and tension in the family, thus triggering anger and conflict at an alarming level. It often results in violent outbursts and excessive mental stress. During the period of Large-Scale Social Restrictions (PSBB) or Lockdown, we need to pay attention to the tendency that there is no way out for victims of family-based violence (usually women and children). Sexual abuse of children in the family is another area where they have almost no escape or escape during the Pandemic that the lockdown policy dissertates on. We can say that in a pandemic emergency, women who traditionally served at home were suddenly burdened by every family member who was forced to stay at home. Women are very likely to lose themselves because their household duties are forced to serve other domains forced to be placed in the house simultaneously. Of course, this requires the wisdom of each party, especially the family and the surrounding community. 
Yeni Huriani, Mohammad Taufiq Rahman, Mochamad Ziaul Haq

Intimate partner violence (IPV), including physical or sexual violence, emotional abuse, and stalking, has increased during social distancing and domestic function. In Indonesia, the term Gender-Based Violence is also known, which is any action against someone committed based on gender and unequal power relations, resulting in physical, psychological, sexual, and neglect pain or suffering, including threats to commit acts, coercion, or unlawful deprivation of liberty, whether that occurs in the domestic or public sphere.

IPV victims are at high risk of experiencing various mental and somatic diseases, such as cardiovascular disease, chronic pain, sleep disturbances, gastrointestinal problems, sexually transmitted infections, traumatic brain injury. UNIFEM data (2020) shows an increase in domestic violence cases in many countries to 30-50 percent during the Pandemic in 2020. The Legal Aid Institute for the Indonesian Women's Association for Justice released, for one month from March 16 - April 19, 2020, in a pandemic era, has received 97 complaints. This number has increased dramatically compared to direct complaints of only 60 complaints a month.

As of October 2020, the National Commission on Violence Against Women has received 1,617 reports covering 1,458 cases of gender-based violence and 159 nongender-based violence. Compared with the previous year, the number of words had increased by 63 percent (Perempuan \& Tahunan, 2020). The data of cases handled by Legal Aid of Jentera Perempuan Indonesia, both legally and non-legally, were recorded as many as 94 cases from January to November 2020 (Lindsey \& Pausacker, 2020). The Palembang Women's Crisis Center (WCC) report states that there has been an increase in violence against women. Gender-Based Violence Online (KBGO) or 'cyber crime' in South Sumatra Province throughout 2020; Until November 2020, it reached 30 cases. This number is increasing compared to the previous year, which was less than 10 cases. Throughout this year, the center has handled 96 cases of violence against women and children, of which 47 were sexual violence (Yuningsiha et al., 2020).

Globally, the United Nations declared the increase in violence as a shadow pandemic alongside COVID-19 worldwide. Staying at home was no longer safer for many women during social restrictions (lockdowns) due to a surge in domestic violence and intimate partner violence. It is associated with social conditions, job loss, 
Yeni Huriani, Mohammad Taufiq Rahman, Mochamad Ziaul Haq

isolation and quarantine at home, and overcrowding of work roles, all of which cause stress and anxiety (Yap, 2020).

The sudden loss of household income creates instability in the family's economic situation and can lead to poverty. Recent research from the United Nations UniversityWorld Institute for Development Economics Research (UNU-WIDER) suggests the occurrence of an economic downturn due to the Pandemic, which could increase world poverty to cover half a billion people or 8 percent of the world's population. Projections of BAPPENAS show that the possibility of Indonesia's population falling into poverty has risen to 55 percent, with around 27 percent of middle-class candidates estimated to experience worrying income insecurity (UNICEF, 2020). Thus, in all crises, whatever and anywhere, if there is an increase in activity pressure in the household accompanied by various deficiencies in the factors that support family survival, it will increase violence in the home and intimate partners. This impact also applies to the WFH and SFH policies as part of the new everyday life.

In these dramatic crises, male aggression is often easier to forgive. When anger is temporary, and there is genuine remorse, it tends to be tolerated and ignored. It is due to the general view that men tend to behave aggressively in crisis pressure situations. Still, women will be considered overreacting when they ask for help to deal with this violence and are even ignored. For women who have a high potential for violence, the home may not be a safe place. However, if women do not have a private location in their homes, many women will find it challenging to find help (Thibaut \& Wijngaarden-Cremers, 2020).

The various economic, social, and physical pressures women face during the Pandemic have undoubtedly negatively impacted mental health. One study found a much more significant decrease in women's mood during the Pandemic than men's spirits. Although there was a gender gap in mental health before the Pandemic, this worry increased by 66\% from late March to mid-April 2020 (Chen \& Bougie, 2020). More complex forms of violence may also occur significantly when the perpetrator can restrict access to psychosocial services and support. Exposure to COVID-19 can pose a threat. Perpetrators of violence can also take advantage of women's inability to ask for help or run away (Thibaut \& Wijngaarden-Cremers, 2020). 
Women may be abandoned on the street or thrown out of the house in some cases when there is a lot of psychological pressure in the family. At least, this symptom can be observed early on from increasing divorce cases during the Pandemic. BBC Worklife reports that a UK law firm, Stewarts, submitted 12\% more divorce applications from July to October 2020. Citizens Advice, a domestic affairs counselor, and the legal agency said requests for divorce consultations were increasing. In the United States, a legal, contractual service provider website states that their revenue from divorce documents has risen by $34 \%$. This phenomenon of growing divorce rates also occurred in China and Sweden during the Pandemic. Lawyers, psychologists, and academics are starting to look more closely at the various factors behind this trend and predict that the increase in divorce will continue to occur in 2021 (Savage, 2020).

In the case in Indonesia, the increase in divorce cases can be observed from the report of the religious court in Surabaya, one of the major cities in Indonesia. As reported by JawaPos.com, from April to December 2020, 2,956 divorce cases were tested. During 2019, there were 1,941 divorce cases. It means that during the Pandemic, the divorce rate has halved. In 2020, 1,300 wives sued for divorce from their husbands. The reason is that the husband leaves his wife because of frequent quarrels and economic factors. An interesting trend for this case in the Surabaya religious court is that the leading cause of divorce during the Pandemic is the abandonment of a wife. Although there are economic factors, this reason is the highest compared to other reasons. Of course, this is a trend that deserves further study and exploration (Ginanjar, 2021).

However, the data above reveals that gender inequality is getting worse during the Pandemic. It is in part exacerbated by reduced access to support services for women's welfare and protection. With many restrictions on care services, such as childcare, care for the elderly, assistance with household tasks, and increased pressure on household work falls disproportionately on women. Under these conditions, women who keep their jobs will get additional stress when balancing work and household. Women with this dual role are at risk of decreasing work productivity and tiring mental stress for women.

Apart from women, children are vulnerable to violence. The violence of children in the family can increase the risk of violence in adult relationships. Sexual violence is 
more likely against girls than boys. Some of the trigger factors include loss of work, decreased income, social restrictions, loss of support for household resilience, narrow living space, loss of loved ones, fear of death and transmission, difficulty in accessing medical and social services, inability to survive, increased consumption of addictive substances, and the like (Febriyani et al., 2020). All these precipitating factors are associated with this increased family violence during the epidemic. Other risk factors are a history of past exposure to parental violence, parental substance abuse, child labor. Simultaneously, the Covid-19 crisis increases the risk of sexual exploitation of children on the internet (Anwar et al., 2018; Thibaut \& Wijngaarden-Cremers, 2020).

Concerning violence against children, low income was the most previously reported risk factor for violence against children. However, school closures and study from home policies increase the risk of violence against children. More than 120 countries have imposed restrictions on social interaction through school closings affecting 1.6 million students worldwide. Since early March, Indonesia has closed all schools so that 60 million students cannot attend school (Candraningrum, 2020). Schools are being asked to facilitate learning from home using some public and private digital platforms that provide free content and online and remote learning opportunities across the region. Although nearly 47 million households (66 percent) have internet access, online distance learning still presents challenges (BPS, 2020).

School closures increase the gap in access to education. Children have faced various difficulties in accessing and getting a quality education, even since before the Pandemic. Indonesia has experienced rapid development in student enrollment over the past decade. However, there are 4.2 million children and adolescents (aged 7-18 years) who still do not attend school. Teenagers dominate this figure. Recent global studies highlight complex learning challenges for children and adolescents in Indonesia; for example, 70 percent of 15-year-old students are not yet proficient in reading and arithmetic. Poor and vulnerable students are the most affected by school closures. Caregivers may not make children's education their top priority because they often struggle to meet basic needs (UNICEF, 2020).

The length of online learning $(\mathrm{SFH})$ causes the interactive learning time to be lost. It results in delays in the mastery of knowledge and abilities according to grade level. This situation poses a risk of increasing the number of children dropping out of school 
Yeni Huriani, Mohammad Taufiq Rahman, Mochamad Ziaul Haq

due to the reduced quality of education of the younger generation accompanied by a prolonged economic contraction. The pressure of this Pandemic will threaten and hamper the long-term well-being of young people.

Various efforts to control the Pandemic have had a significant impact on the economic sector, daily activities, and all aspects of children's lives. This impact may be traumatic for life in some children. There are 80 million children in Indonesia (about 30 percent of the total population) who can experience severe impacts due to various secondary effects arising from a pandemic, both in the short term and long term. Current inequalities can get worse, particularly about gender, income levels, and disabilities. The socio-economic impacts on children in Indonesia as a result of the COVID-19 Pandemic and various related efforts to reduce transmission rates and control the Pandemic can be grouped into four categories: (i) child poverty, (ii) learning, (iii) nutrition, and (iv) care and security. Statement. In other words, "children are invisible victims" given the short and long-term impacts on the child's health, welfare, development, and future (UNICEF, 2020).

\section{CONCLUSION}

Every party must see the positive side of this Pandemic as an opportunity to build a better and more resilient society through encouragement to build gender-based power relations justice is facing new realities during the Pandemic, especially in the demands of the WFH and SFH systems. We hope that this Pandemic will open people's awareness to recognize and appreciate women's central role at home and work. Indonesians must empower the facilities that have been carried out by the Indonesian Ministry of Women's Empowerment and Child Protection in collaboration with the United Nations Fund for Population Activities (UNFPA) to adopt the Guidelines for Handling Gender-Based Violence compiled by P2TP2A DKI Jakarta, the Foundation recover the Joint Service Provider Institution of the Ministry of PPA and UNFPA in 2020.

This effort resulted in a protocol for handling cases of violence against women. Women who become victims can still be adequately served, and service provider institutions can still provide case handling by referring to the existing Protocol. The Protocol in question is as follows: (1) Protocol for complaints of cases of violence 
Yeni Huriani, Mohammad Taufiq Rahman, Mochamad Ziaul Haq

against women during the COVID-19 Pandemic; (2) Protocol for providing assistance services for violence against women during the COVID-19 Pandemic; (3) Protocol for referral to health services on violence against women during the COVID-19 Pandemic; (4) Protocol for referral to safe houses or shelters for violence against women during the COVID-19 Pandemic; (5) Protocol for psychosocial services for violence against women during the COVID-19 Pandemic; (6) Protocol for legal counseling services on violence against women during the COVID-19 Pandemic; (7) Protocol for legal process assistance on violence against women during the COVID-19 Pandemic; and (8) Protocol for the rescue of victims of violence against women during the COVID pandemic.

The implementation of the above requires the participation of women and men, all family members, the Government, and every party involved in efforts to live a new everyday life in a positive and gender-based justice orientation. It can be done by utilizing various protocol policies that protect women, children, and every family member. Pandemic does not let us lose the moment to rewrite our minds and hearts so that our priorities and commitments flow together into a world of peace and prosperity, mutual respect, and sharing of responsibilities with one another. This research is a first and strategic step to build concern for the justice of gender-based power relations in the family domain, starting from building awareness in the smallest unit in society, namely ourselves and our families.

\section{REFERENCES}

Altena, E., Baglioni, C., Espie, C. A., Ellis, J., Gavriloff, D., Holzinger, B., Schlarb, A., Frase, L., Jernelöv, S., \& Riemann, D. (2020). Dealing with sleep problems during home confinement due to the COVID-19 outbreak: Practical recommendations from a task force of the European CBT-I Academy. Journal of Sleep Research, 29(4), e13052. https://doi.org/10.1111/jsr.13052.

Anwar, R. K., Rizal, E., \& Rahman, M. T. (2018). Consideration of Parents' Beliefs about Guiding Children's Usage of the Internet. https:/ / doi.org/10.5220/0008818901950199

BPS. (2020). Badan Pusat Statistik.

Candraningrum, D. (2020). Ketika Cinta Membunuh: Dinamika Terminologi dan Matra Kekerasan Domestik Selama Pandemi COVID-19.

Chen, I., \& Bougie, O. (2020). Women's Issues in Pandemic Times: How COVID-19 Has

Exacerbated Gender Inequities for Women in Canada and around the World. Journal of Obstetrics and Gynaecology Canada, 42(12), 1458-1459.

https://doi.org/10.1016/j.jogc.2020.06.010

Chung, C. K. L., Xu, J., \& Zhang, M. (2020). Geographies of Covid-19: how space and virus 
Yeni Huriani, Mohammad Taufiq Rahman, Mochamad Ziaul Haq

shape each other. Asian Geographer, 37(2), 99-116.

https:/ / doi.org/https:/ / doi.org/10.1080/10225706.2020.1767423

Erdirençelebi, M. (2020). Work-Family Life Balance in the Changing Business World. In Contemporary Global Issues in Human Resource Management. Emerald Publishing Limited.

Febriyani, R., Rostika, I., \& Rahman, M. T. (2020). Peran Keluarga dan Bimbingan Sufistik dalam Mengembangkan Religiusitas Anak. Prodi S2 Studi Agama-Agama UIN Sunan Gunung Djati Bandung. http:// digilib.uinsgd.ac.id/id/eprint/33190

Ginanjar, D. (2021). Selama Pandemi , Banyak Istri di Surabaya yang Tinggalkan Suami Pengacara Perceraian - Gratis Konsultasi. JAWAPOS.

Guterres, A. (2020). A time to save the sick and rescue the planet. New York Times. https://www.nytimes.com/2020/04/28/opinion/coronavirus-climate-antonioguterres.html

Kabeer, N., Razavi, S., \& van der Meulen Rodgers, Y. (2021). Feminist economic perspectives on the COVID-19 pandemic. Taylor \& Francis. https:// doi.org/https:/ / doi.org/10.1080/13545701.2021.1876906

Koren, C., \& Ayalon, L. (2020). Envy and Jealousy of Living apart Together Relationships in Continuing Care Retirement Communities: Perspectives of Staff and Residents. The British Journal of Social Work.

https://doi.org/https://dx.doi.org/10.1093\%2Fgeroni\%2Figaa057.1231

Lindsey, T., \& Pausacker, H. (2020). Crime and Punishment in Indonesia. Routledge. https://doi.org/https:// doi.org/10.4324/9780429455247

Organization, W. H. (2020a). COVID-19 health equity impact policy brief: informal workers. World Health Organization. Regional Office for Europe. https://apps.who.int/iris/handle/10665/338203

Organization, W. H. (2020b). Getting your workplace ready for COVID-19: how COVID-19 spreads, 19 March 2020. World Health Organization. https://apps.who.int/iris/handle/10665/331584

Perempuan, K., \& Tahunan, C. (2020). Komnas Perempuan. Retrieved from Komnasperempuan. Go. Id: Https://Www. Komnasperempuan. Go. Id/Read-News-Menemukenali-Kekerasan-DalamRumah-Tangga-Kdrt. https://komnasperempuan.go.id/siaran-pers-detail/catahu-2020komnas-perempuan-lembar-fakta-dan-poin-kunci-5-maret-2021

Power, K. (2020). The COVID-19 pandemic has increased the care burden of women and families. Sustainability: Science, Practice and Policy, 16(1), 67-73. https://doi.org/https:// doi.org/10.1080/15487733.2020.1776561

Savage, M. (2020). Why the pandemic is causing spikes in break-ups and divorces. BBC Worklife. https://www.bbc.com/worklife/article/20201203-why-the-pandemic-is-causingspikes-in-break-ups-and-divorces

Statistik, B P. (2018). Booklet Survei Angkatan Kerja Nasional Februari 2018. https://www.bps.go.id/publication/2018/09/28/c49b09bd9fcb72050c51958e/bookletsurvei-angkatan-kerja-nasional-februari-2018.html

Statistik, Badan Pusat. (2020). Pencegahan Perkawinan Anak. Jakarta: Kementerian Perencanaan Pembangunan Nasional.

The Lancet. (2020). COVID-19: fighting panic with information. The Lancet, 395(10224), 537. https://doi.org/10.1016/S0140-6736(20)30379-2

Thibaut, F., \& Wijngaarden-Cremers, P. J. M. van. (2020). Women's Mental Health in the Time of Covid-19 Pandemic. Frontiers in Global Women's Health, 1(December), 1-6. https://doi.org/10.3389/fgwh.2020.588372

Trilla, A. (2020). One world, one health: The novel coronavirus COVID-19 epidemic. Medicina Clínica (English Edition), 154(5), 175-177. https:/ / doi.org/10.1016/j.medcle.2020.02.001

Trougakos, J. P., Chawla, N., \& McCarthy, J. M. (2020). Working in a pandemic: Exploring the impact of COVID-19 health anxiety on work, family, and health outcomes. Journal of Applied Psychology, 105(11), 1234. https://doi.org/https://doi.org/10.1037/ap10000739

Equalita: Jurnal Studi Gender dan Anak, Volume (3), Issue (1), Juni 2021 
Yeni Huriani, Mohammad Taufiq Rahman, Mochamad Ziaul Haq

Troup, C., \& Rose, J. (2012). Working from home: Do formal or informal telework arrangements provide better work-family outcomes? Community, Work and Family, 15(4), 471-486. https:/ / doi.org/10.1080/13668803.2012.724220

UNICEF. (2020). COVID-19 dan Anak-Anak di Indonesia Agenda Tindakan untuk Mengatasi Tantangan Sosial Ekonomi. In UNICEF (Vol. 1, Issue Mei).

https://www.unicef.org/indonesia/sites/unicef.org.indonesia/files/2020-05/COVID19-dan-Anak-anak-di-Indonesia-2020_1.pdf

Wong, A. H. K., Cheung, J. O., \& Chen, Z. (2020). Promoting effectiveness of "working from home": findings from Hong Kong working population under COVID-19. Asian Education and Development Studies. https://doi.org/10.1108/ AEDS-06-2020-0139

Yap, O. F. (2020). A new normal or business-as-usual? Lessons for COVID-19 from financial crises in East and Southeast Asia. The European Journal of Development Research, 32(5), 1504-1534. https://doi.org/https://doi.org/10.1057/s41287-020-00327-3

Yuningsiha, H., Nurjayab, I. N., Djatmikab, P., \& Ruba' Ib, M. (2020). Philosophical Foundation of Chemical Castration for Offenders of Sexual Violence Against Children. Sriwijaya Law Review, 4(1), 62-78. 